\title{
Ecological Characteristics of Two Closely Related Rodent Species in Urban Environment-Permanent Inhabitant vs Newcomer
}

\author{
Agnieszka Pieniążek*, Miłosława Sokół, Michał Kozakiewicz \\ Department of Ecology, Faculty of Biology, Biological and Chemical Research Centre, University of Warsaw, Warsaw, Poland \\ Email: *a.pieniazek@biol.uw.edu.pl
}

How to cite this paper: Pieniążek, A., Sokól, M. and Kozakiewicz, M. (2017) Ecological Characteristics of Two Closely Related Rodent Species in Urban Environment-Permanent Inhabitant vs Newcomer. Natural Resources, 8, 69-80. https://doi.org/10.4236/nr.2017.82005

Received: December 28, 2016

Accepted: February 5, 2017

Published: February 8, 2017

Copyright (๑) 2017 by authors and Scientific Research Publishing Inc. This work is licensed under the Creative Commons Attribution International License (CC BY 4.0).

http://creativecommons.org/licenses/by/4.0/ (c) (i) Open Access

\begin{abstract}
The aim of the study was to characterize natural and urban populations of two Apodemus species-the striped field mouse (Apodemus agrarius) and the yellow-necked mouse (Apodemus flavicollis) - seeking to verify whether the different durations of synurbization have led populations of the two species to exhibit differing characteristics. The study was conducted in central Poland (in Warsaw and its surrounds, in urban parks in the city center and in natural habitats outside the city) over two seasons, during which a total of 1751 striped field mice and 454 yellow-necked mice were live-trapped (using the catch-mark-release method). We found altered characteristics of urban populations of striped field mice, which we interpret as the result of the relatively lengthy synurbization of the species over the last hundred years and its adaptation to the highly modified urban environment. A significantly higher percentage of sexually-active males and a higher average body mass were observed for the urban population of striped field mice, suggesting that the species is in better condition in urban habitats. We found urban populations of yellow-necked mice, in turn, to be unstable (as reflected in a high turn-over rate and a low percentage of retrapped mice), their survival in urban habitats only being made possible by ongoing attempts at colonization. We conclude that, in urban habitats, the system of competition between the two species exhibits a certain shift in favor of striped field mice-typically a weaker species, but the first to colonize cities. Overall, we conclude that the conditions present in urban habitats act as a strong factor shaping populations with characteristics different from those found in natural habitats. This is further enhanced by the priority effect, resulting from differing durations of urban habitation and adaptation, leading to changes in the system of competition between species.
\end{abstract}




\section{Keywords}

Urbanization, Small Mammals, Urban Population, Apodemus, Priority Effect

\section{Introduction}

As the number and size of cities around the world continue to surge [1], increasing urbanization is also shrinking the natural habitats of many species, forcing them into synurbization. This occurs either by active penetration of species into cities from outside, or as a result of populations becoming enclosed within cities as they expand, a phenomenon known as urban trap [2].

Urban habitats differ from natural, non-urban habitats in numerous ways [3]. Cities are characterized by transformed abiotic conditions, high levels of light and noise, pollution of the soil, water and air, a milder climate, later arrival of winter and earlier arrival of spring, elevated temperatures due to a high heat capacity of anthropogenic surfaces, a lower diurnal and seasonal variation in temperature, etc. [3]. Cities also offer a high availability of anthropogenic food, which-in combination with the milder climate-allows many species to extend their breeding season [4].

In addition to such physicochemical factors, the spatial structure of cities is also an important element shaping urban populations. Green areas within cities are highly heterogeneous [3], comprising numerous patches of varying size and quality, interspersed by regions with a high density of buildings and busy transport routes. This leads to the formation of numerous highly isolated microenvironments [5].

Many authors have reported that increasing urbanization leads to the depletion and homogenization of populations of animals inhabiting cities [6]. Many species, such as the feral pigeon (Columba livia urbana), brown rat (Rattus norvegicus), and house sparrow (Passer domesticus), are found in vast numbers in cities across a range of latitudes [7]. Species composition in urban areas has been found to decrease as the gradient of anthropopressure in those areas increases [8]. Differing conditions in urban habitats also affect the pressure exerted on urban animal populations by parasites, competitors, and natural predators.

Given the specific conditions of urban habitats, the animal populations living in them generally develop different characteristics than those found in natural habitats. Research into urban populations of species such as the blackbird (Turdus merula) and the striped field mouse (Apodemus agrarius) has found them to be characterized by higher population densities, longer breeding seasons, lower turn-over rate, lower mortality rates in adult individuals, and higher survival rates in winter [9] in comparison with populations found in natural habitats. Many authors also indicate that due to the high component of highly calorific food from anthropogenic sources in their diet, adult individuals in urban populations have a higher average body mass-as found, for instance in the striped field mouse [10]. Animal behavior has also been observed to differ in cities [11]. 
Different abiotic conditions in cities and the spatial structure supporting the isolation of small patches of the environment frequently lead to greater genetic differentiation between isolated local populations within cities and in comparison to natural populations [2] [12]. Additionally, within isolated local populations, genetic variability is frequently reduced and the degree of relatedness between individuals is increased [13] [14], in particular in species with a limited mobility [15] [16] for whom crossing anthropogenic barriers is difficult or impossible.

It can be expected that adaptive changes in synurbic populations arising through microevolution and leading to the development of specific behavioral, physiological, and ecological characteristics making them distinct from natural populations [17] become more marked and enduring the longer the species has been synurbized, which means they depend on the length of the process of adaptation to the new urban habitat. We resolved to test this hypothesis by studying the populations of two species of small rodents from the Apodemus genus in the city of Warsaw, Poland, which differ in terms of the duration of their synurbization.

\section{Material and Methods}

\subsection{Study Species}

We investigated two Apodemus species common in Poland, differing in time of Warsaw city inhabitation. This makes them a good model for checking if the duration of synurbization process affects population characteristics. The first of these, the striped field mouse (Apodemus agrarius) (Figure 1), chiefly inhabits open terrain such as fields, meadows and fallow land, and it is frequently found on the edges of forests. The species was first noted in green areas in Warsaw in

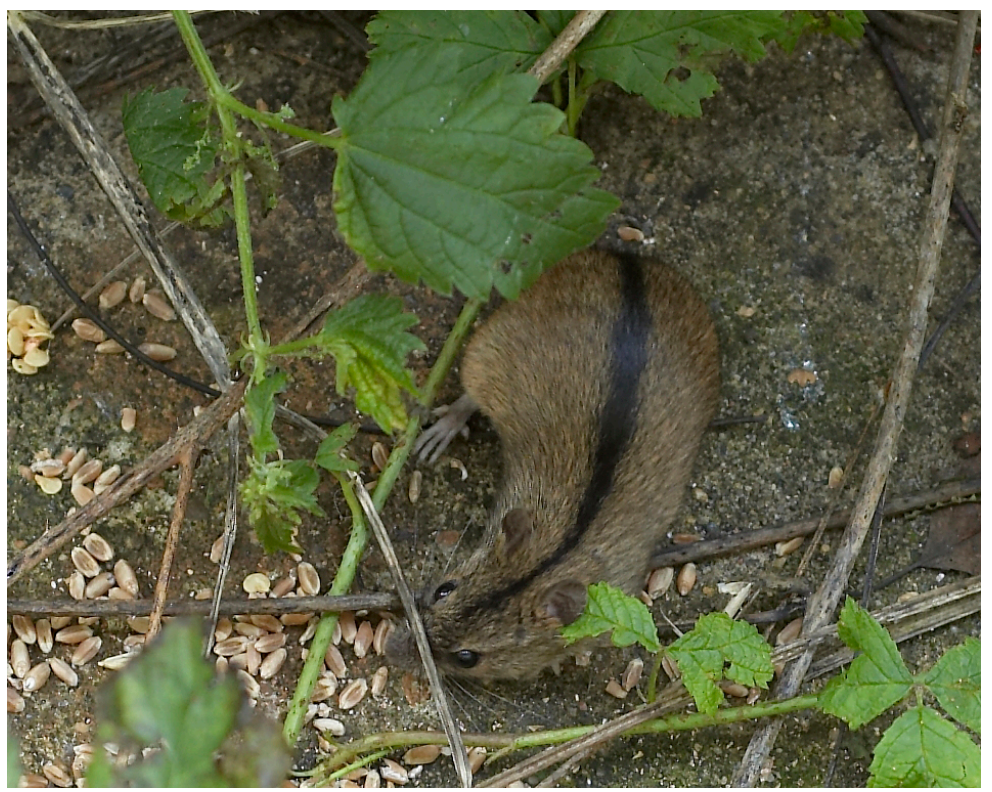

Figure 1. Striped field mouse (Apodemus agrarius). Photo by Fibro, distributed under a CC BY-SA 3.0 licence (https://creativecommons.org/licenses/by-sa/3.0/). 
the late nineteenth century [18], and by the early twentieth century it was described as often found in the city [19]. The second species, the yellow-necked mouse (Apodemus flavicollis) (Figure 2), favors green areas with a good forest coverage or near large forests, with dense vegetation and developed undergrowth and a high-proportion of seed-bearing trees. Yellow-necked mice were first recorded in Warsaw's green areas less than 10 years ago [20], prior to which the species was only found in distant suburbs [21].

\subsection{Study Area and Field Methods}

The study was conducted in Warsaw $\left(52^{\circ} 26^{\prime} \mathrm{N}, 21^{\circ} 02^{\prime} \mathrm{E}\right)$ and its surrounds in central Poland, (central Europe, temperate climate) (Figure 3). Research was carried out at five locations (three in city parks within the city center and two in natural habitats outside the city), over two full seasons, from spring 2014 until spring 2016. Each year, four series of live-trappings (using the catch-mark-release method) were conducted over the course of five days; this was done in spring (April), early summer (June), summer (August) and autumn (October). Nine trappings were conducted in total. A line was marked out at each site with 30 points placed approx. 20 meters apart, with two traps at each point. Trapped individuals were identified in terms of species and tagged with a numbered earring, weight and sex, and their degree of sexual activity was noted; they were then released at the same point where they were caught (permission given by First Warsaw Local Ethics Committee for Animal Experimentation no. 550/ 2014). Sexually active individuals included males with visibly enlarged testicles and females that were pregnant, lactating or had a visible vaginal opening.

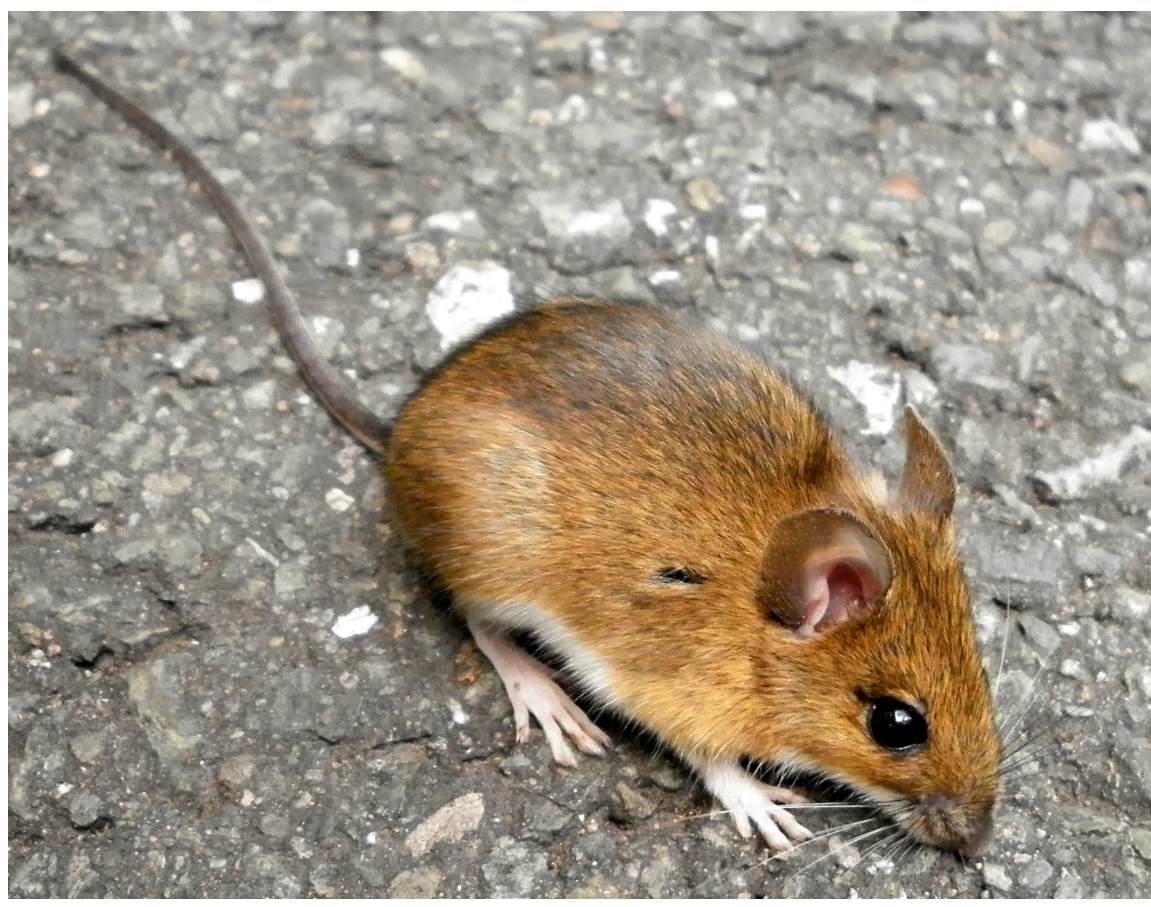

Figure 2. Yellow-necked mouse (Apodemus flavicollis). Photo by Vojtech.dostal, distributed under a CC BY-SA 3.0 licence (https://creativecommons.org/licenses/by-sa/3.0/). 


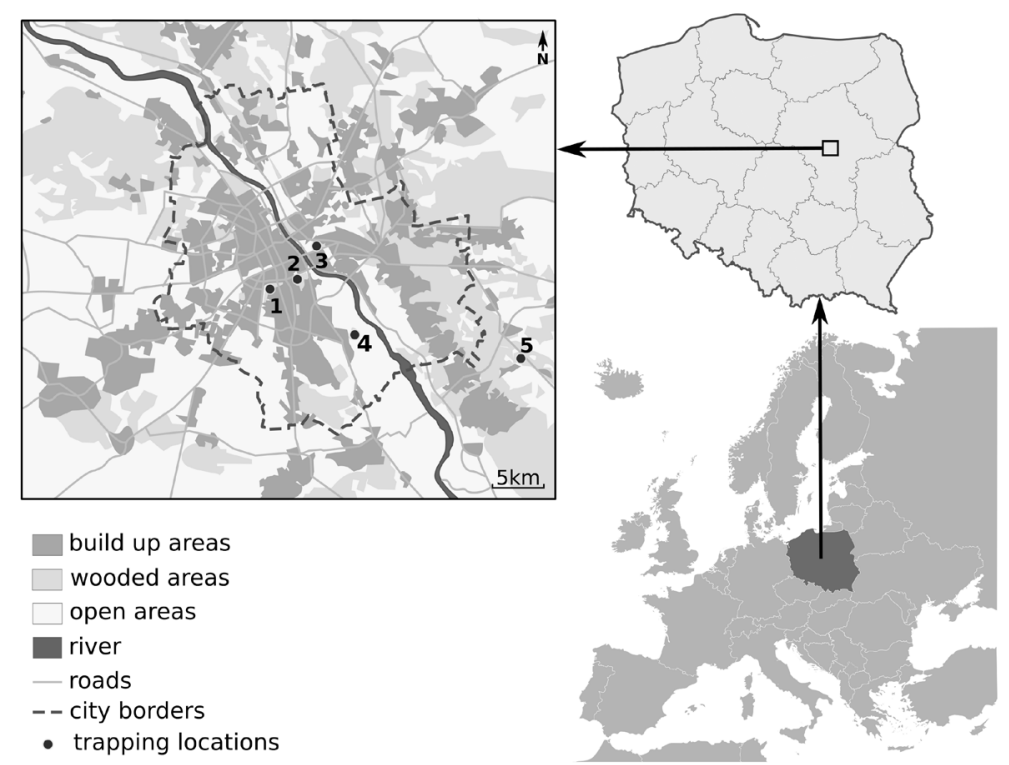

Figure 3. Map of the studied area showing the rodent trapping locations. Numbers on the map mean particular locations: 1 - 3-urban locations, 4 - 5-non-urban locations.

A total of 1751 striped field mice and 454 yellow-necked mice were caught during the study. Since the trends were very similar for all urban locations and both non-urban locations, the results shown below are organized into groups and comparisons are drawn jointly for urban and non-urban locations. The chi-square test was carried out to verify the results; the significance level was set at $p=0.05$.

\section{Results}

\subsection{Population Dynamics and Turn-Over Rate}

Populations of striped field mice from non-urban habitats were significantly less numerous than urban populations, peaking in summer (Figure 4). Urban populations were characterized by high, steady numbers, also peaking in summer (Figure 4).

Populations of yellow-necked mice from non-urban habitats had stable, low numbers, peaking in autumn (Figure 4). In contrast to the non-urban populations, the urban populations of yellow-necked mice peaked in early summer and the numbers were relatively low and steady (Figure 4).

The turn-over rate in groups of animals tagged during the various stages was lower in urban populations of striped field mice (Figure 5(b)) than non-urban populations (Figure 5(a)). In contrast to striped field mice, in yellow-necked mice a lower turn-over rate was observed in non-urban (Figure 5(c)) than urban populations (Figure 5(d)).

The turn-over rates [22] were markedly different for striped field mice and yellow-necked mice; the average time spent in the population by striped field mice was 110 days during the first year and 130 days during the second year, while for yellow-necked mice, the number was 99 during both years. 


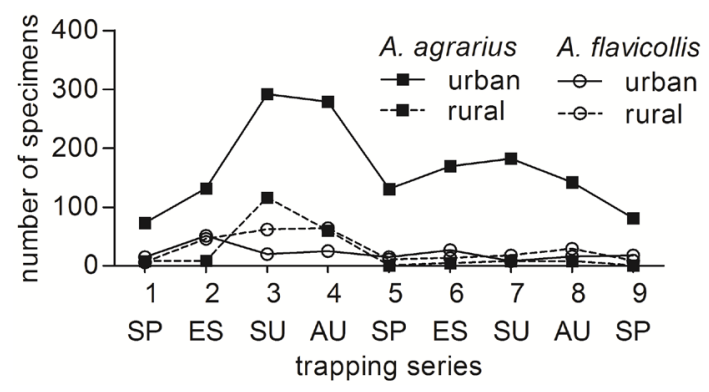

Figure 4. Variations in numbers of striped field mouse ( $A$. agrarius) and yellow-necked mouse (A. flavicollis) in urban and rural populations. Trapping series numbering 1 - 9 done respectively in: SP_spring, ES-early summer, SU-summer, AU-autumn.

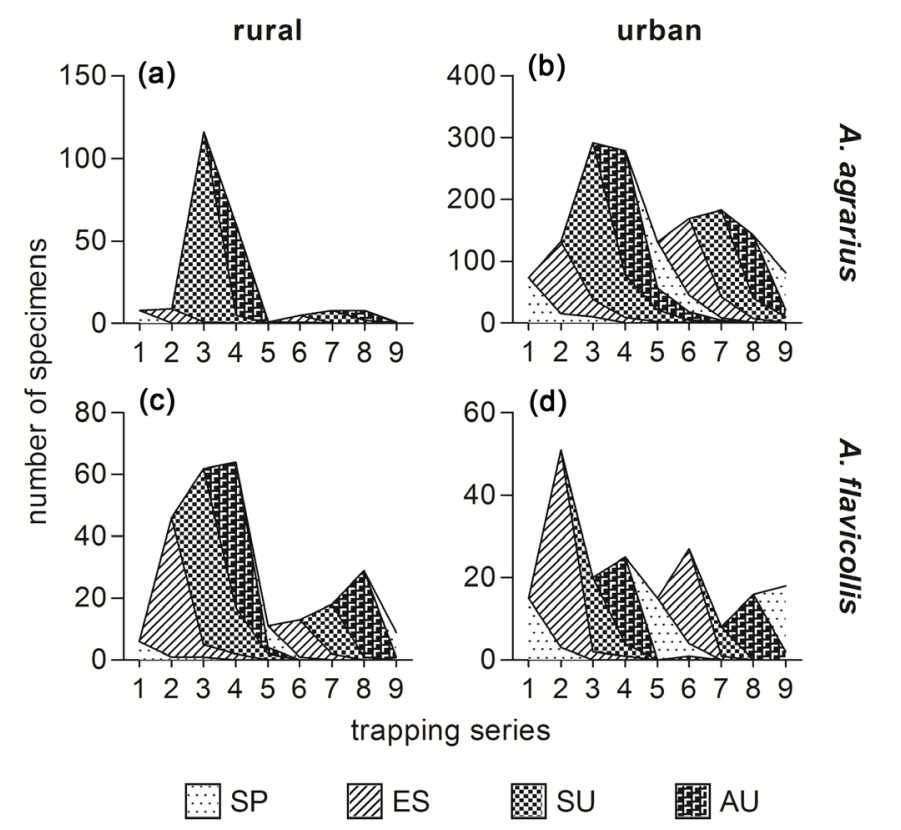

Figure 5. Dynamics of group of individuals marked at the same time in the rural (a) and urban (b) populations of striped field mouse and in the rural (c) and urban (d) populations of yellow-necked mouse; SP-animals marked in spring, ES-animals marked in early summer, SU-animals marked in summer, AU-animals marked in autumn. To maintain readability results axis ranges are different.

No significant differences were found in non-urban populations for either species. The average times spent in the population by individuals were similar, with 94 days during the first year and 106 days during the second year for striped field mice and 105 and 101 days, respectively, for yellow-necked mice.

Individuals from urban populations of striped field mice spent a longer average time in the population than those from non-urban populations. No differences were found between populations of yellow-necked mice.

Non-urban populations of yellow-necked mice were characterized by a higher proportion of previously marked individuals $(p<0.001)$ and a significantly lower proportion of disappearing individuals $(p<0.01)$ than non-urban populations of striped field mice (Figure 6). In contrast, urban populations of striped field mice were characterized by a significantly higher proportion of previously 


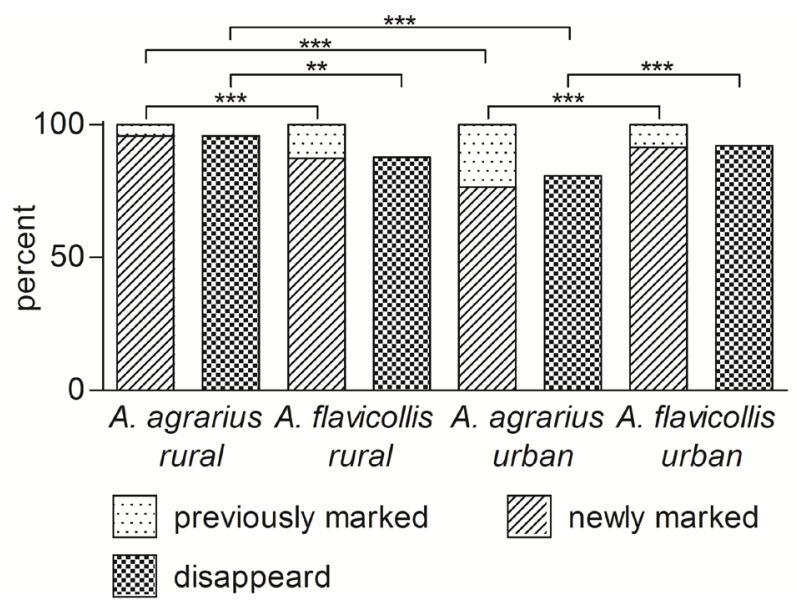

Figure 6. Percentage of incoming animals (newly-marked), previously marked and disappearing from rural and urban populations of striped field mice and yellow-necked mice. The comparison included series $2-8$, meaning those preceded and followed by at least one series. Statistical significance levels: ${ }^{\star} p<0.05 ;{ }^{\star *} p<0.01 ;{ }^{\star * *} p<0.001$.

marked individuals $(p<0.001)$ and a significantly lower proportion of disappearing individuals $(p<0.001)$ than populations of yellow-necked mice (Figure 6).

Comparisons of populations of striped field mice reveal that urban populations were characterized by a significantly higher proportion of previously marked individuals $(p<0.001)$ and a significantly lower proportion of disappearing individuals $(p<0.001)$ than non-urban populations (Figure 6). Comparisons of urban and non-urban populations of yellow-necked mice did not find statistically significant differences in the percentage of previously marked individuals or percentage of disappearing individuals (Figure 6).

\subsection{Sex and Sexual Activity}

Comparisons of populations of both species did not show statistically significant differences in the percentages of sexually-active males in urban and non-urban habitats (Figure 7(a)). No statistically significant differences in the proportion of sexually-active males were found in urban and non-urban populations of yellow-necked mice (Figure 7(a)). We found a statistically significant greater percentage of sexually-active males in urban populations of striped field mice $(p<$ 0.001) (Figure 7(a)).

In non-urban habitats, the percentage of sexually-active females was found to be statistically significantly higher in yellow-necked mice than in striped field mice $(p<0.01)$ (Figure 7(b)). Comparisons of urban and non-urban populations of both species showed no statistically significant differences.

In urban populations of striped field mice we found a statistically significant $(p<0.05)$ higher percentage of pregnant and lactating females than in yellow-necked mice (Figure 7(c)). Comparisons of the urban and non-urban populations of the two species showed no statistically significant differences (Figure $7(c))$. 


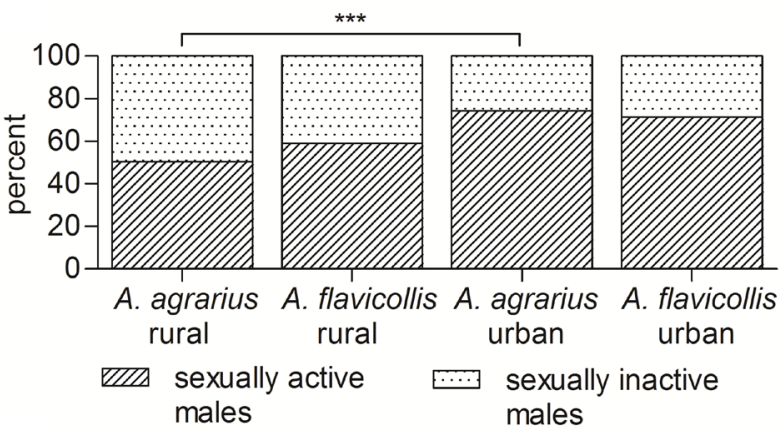

(a)

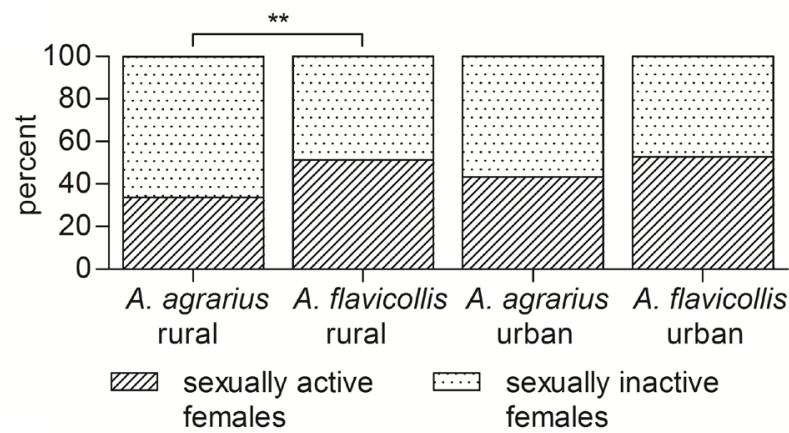

(b)

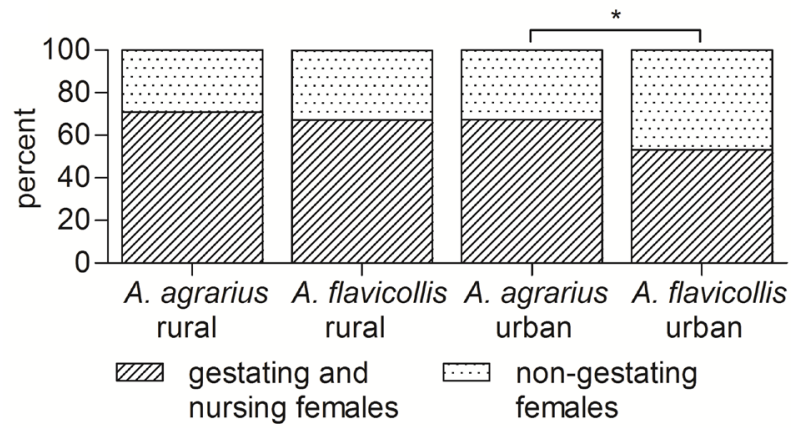

(c)

Figure 7. Percentage of sexually active individuals in group of males (a) and females (b) and percentage of gestating and nursing females in the group of sexually active females (c) in populations of striped field mouse ( $A$. agrarius) and yellow-necked mouse $(A$. flavicollis) in urban and rural localizations. Statistical significance levels: ${ }^{\star} p<0.05$; ${ }^{\star *} p<$ $0.01 ;{ }^{* *} p<0.001$.

\subsection{Body Mass}

We found sexually-active male striped field mice from urban populations to have a statistically significant higher $(p<0.001)$ average body mass than those from non-urban populations. No statistically significant differences were found in sexually-active males of yellow-necked mice from both habitats.

\section{Discussion}

In the non-urban populations of the two species we studied, the yellow-necked mouse exhibited higher numbers, better survival rates between successive stages, a significantly higher percentage of previously marked individuals, lower per- 
centages of disappearing individuals, and a significantly higher proportion of sexually-active females. These findings support the conclusion that populations of yellow-necked mice in natural, non-urban habitats are in significantly better condition than those of striped field mice. Our results are in line with the typical system of competition among three common small rodent species found in natural habitats in central Poland, as described in the literature [23], whereby striped field mice are the weakest species and their populations are shaped by strong interactions with other species which are competitively stronger. It is generally thought that the presence of striped field mice in urban habitats is the result of the species being displaced from its natural habitats by competitively stronger species, in particular yellow-necked mouse [21] [23] [24].

In the urban populations, the striped field mice showed significantly higher numbers, lower turn-over rate, longer average time spent in the population, higher percentages of individuals previously trapped and lower percentages of disappearing individuals than non-urban populations, indicating the stability of the species' populations in urban habitats. Additionally, we found statistically significantly higher numbers of sexually-active males and their higher average body mass in urban populations of striped field mice than in their non-urban populations, as well as significantly higher numbers of pregnant and lactating females in sexually-active females, which suggests that urban populations of striped field mice are stable and generally in better condition than non-urban populations of the species.

Striped field mice were not found in Warsaw until the late nineteenth century; by the 1920s the species was described as common in the city [19] and in the 1970 s it was clearly dominant in green spaces in the city center [21]. Recent studies of the small rodent communities in Warsaw [8] show that striped field mice are the only small rodent species (apart from brown rats and house mice) which are comfortable in cities and are common in green spaces and parks in Warsaw, even if they are small and frequented by people [8]. Additionally, genetic studies show genetic differences between urban populations of striped field mice in Warsaw and in their natural, non-urban populations, as well as between small highly isolated urban populations of the species [12]. Changes in urban populations of striped field mice are the result of the synurbization of the species over the last hundred years and its adaptation to the strongly altered urban environment.

The absence of significant differences in the length of time particular individuals spend in a given population, the percentage of previously marked individuals and disappearing individuals, sexually-active individuals and average body mass of sexually-active males between urban and non-urban populations of yellow-necked mice is due to the species' short synurbization in Warsaw, as a result of which its urban populations have not yet developed different characteristics in these respects.

Yellow-necked mice were first recorded in green areas in central Warsaw less than 10 years ago [20]. Previously the species was only found in distant suburbs 
near large forests [21]. Urban populations of yellow-necked mice are characterized by extremely low numbers and shifted population peaks in comparison with non-urban populations and with urban populations of striped field mice. We found that urban populations of yellow-necked mice are unstable, as reflected in a high rate of replacement of individuals and a low percentage of retrapped mice, and their survival in urban habitats is only made possible by ongoing attempts at colonization. This is confirmed by genetic studies which show no significant genetic differences between urban and non-urban populations of the species [25].

Changing population dynamics and different population peaks in striped field mice may indicate that yellow-necked mice are retreating in urban habitats in spite of competitive interactions typical of the species [23]. Due to the earlier synurbization of striped field mice and the longer time they have had to adapt to significantly different habitats, the typical competition system between the two species has been altered; as a result the priority effect [26] [27] places striped field mice in an advantageous position even though it is a competitively weaker species than the yellow-necked mouse.

Studies such as Fukami [28] have found that the smaller the ecosystems, the more powerful the priority effect, due to intensified competition between smaller numbers of species and higher population density of the species which was first to inhabit the area. We can assume, then, that in urban populations of plants and animals this effect will be intensified due to the small size and significant isolation of green spaces in cities and a significantly simplified species structure of many such habitats. Additionally, an absence of natural predators may further enhance the priority effect in urban populations [29].

\section{Conclusion}

Our findings support the overall conclusion that the conditions present in urban habitats act as a strong inducement causing populations to develop characteristics different from those found in natural habitats. Crucially, this may be further enhanced by the priority effect, resulting from differing durations of urban habitation and adaptation, leading to changes in the system of competition between species.

\section{Acknowledgements}

The study was carried out at the Biological and Chemical Research Centre, University of Warsaw, established within the project co-financed by European Union from the European Regional Development Fund under the Operational Programme Innovative Economy, 2007-2013.

\section{References}

[1] Antrop, M. (2004) Landscape Change and the Urbanization Process in Europe. Landscape and Urban Planning, 67, 9-26.

https://doi.org/10.1016/S0169-2046(03)00026-4 
[2] Wandeler, P., Funk, M., Largiader, R., Gloor, S. and Breitenmoser, U. (2003) The City-Fox Phenomenon: Genetic Consequences of a Recent Colonization of Urban Habitat. Molecular Ecology, 12, 647-656. https://doi.org/10.1046/j.1365-294X.2003.01768.x

[3] Werner, P. (2011) The Ecology of Urban Areas and Their Functions for Species Diversity. Landscape and Ecology Engineering, 7, 231-240.

https://doi.org/10.1007/s11355-011-0153-4

[4] Moller, A.P., Diaz, M., Flensted-Jensen, E., Grim, T., Ibáñez-Alamo, J.D., Jokimäki, J., Mänd, R., Markó, G. and Tryjanowski, P. (2012) High Urban Population Density of Birds Reflects Their Timing of Urbanization. Oecologia, 170, 867-875. https://doi.org/10.1007/s00442-012-2355-3

[5] Dickman, C.R. and Doncaster, C.P. (1987) The Ecology of Small Mammals in Urban Habitats I. Populations in a Patchy Environment. Journal of Animal Ecology, 56, 629-640. https://doi.org/10.2307/5073

[6] McKinney, M.L. (2002) Urbanization, Biodiversity, and Conservation. BioScience, 52, 883-890. https://doi.org/10.1641/0006-3568(2002)052[0883:UBAC]2.0.CO;2

[7] McKinney, M.L. (2006) Urbanization as a Major Cause of Biotic Homogenization. Biological Conservation, 127, 247-260. https://doi.org/10.1016/j.biocon.2005.09.005

[8] Gortat, T., Barkowska, M., Gryczyńska-Siemiątkowska, A., Pieniążek, A., Kozakiewicz, A. and Kozakiewicz, M. (2014) The Effects of Urbanization-Small Mammal Communities in a Gradient of Human Pressure in Warsaw City, Poland. Polish Journal of Ecology, 62, 177-186. https://doi.org/10.3161/104.062.0115

[9] Gliwicz, J., Goszczyński, J. and Luniak, M. (1994) Characteristic Features of Animal Populations under Synurbization-The Case of the Blackbird and of the Striped Field Mouse. Memorabilia Zoologica, 49, 237-244.

[10] Liro, A. (1985) Variation in Weights of Body and Internal Organs in the Field Mouse in a Gradient of Urban Habitats. Acta Theriologica, 30, 359-377. https://doi.org/10.4098/AT.arch.85-26

[11] Lowry, H., Lill, A. and Wong, B.B. (2013) Behavioural Responses of Wildlife to Urban Environment. Biological Reviews, 88, 537-549. https://doi.org/10.1111/brv.12012

[12] Gortat, T., Rutkowski, R., Gryczyńska, A., Pieniążek, A., Kozakiewicz, A. and Kozakiewicz, M. (2015) Anthropopressure Gradients and the Population Genetic Structure of Apodemus agrarius. Conservation Genetics, 16, 649-659.

https://doi.org/10.1007/s10592-014-0690-0

[13] Rutkowski, R., Rejt, Ł., Gryczyńska-Siemiątkowska, A. and Jagołkowska, P. (2005) Urbanization Gradient and Genetic Variability of Birds-Example of Kestrels in Warsaw. Berkut, 14, 130-136.

[14] Munshi-South, J. (2012) Urban Landscape Genetics: Canopy Cover Predicts Gene Flow between White-Footed Mouse (Peromyscus leucopus) Populations in New York City. Molecular Ecology, 21, 1360-1378. https://doi.org/10.1111/j.1365-294X.2012.05476.x

[15] Munshi-South, J., Zak, Y. and Pehek, E. (2013) Conservation Genetics of Extremely Isolated Urban Populations of the Northern Dusky Salamander (Desmognathus fuscus) in New York City. PeerJ, 1, e64. https://doi.org/10.7717/peerj.64

[16] Noël, S., Ouellet, M., Galois, P. and Lapontaine, F.J. (2007) Impact of Urban Fragmentation on the Genetic Structure of the Eastern Red-Backed Salamander. Conservation Genetics, 8, 599-606. https://doi.org/10.1007/s10592-006-9202-1

[17] Evans, K.L., Hatchwell, B.J., Parnell, M. and Gaston, K.J. (2010) A Conceptual 
Framework for the Colonisation of Urban Areas: The Blackbird Turdus merula as a Case Study. Biology Review, 85, 643-667.

[18] Wałecki, A. (1881) Fauna zwierząt ssących Warszawy i jej stosunek do fauny całego kraju. Pamiętnik Fizjograficzny, 1, 268-291. (In Polish)

[19] Sumiński, S.M. (1922) Fauna Warszawy. Ziemia, 12, 328-335. (In Polish)

[20] Babińska-Werka, J. and Malinowska, B. (2008) Synurbization of the Yellow-Necked Mouse Apodemus flavicollis in Warsaw. In: Indykiewicz, P., Jerzak, L. and Barczak, T., Eds., Fauna of Cities: Preservation of Biodiversity in Cities, ATR, Bydgoszcz, 144-150. (In Polish with English Abstract).

[21] Andrzejewski, R., Babińska-Werka, J., Gliwicz, J. and Goszczyński, J. (1978) Synurbization Processes in Population of Apodemus agrarius I. Charakteristics of Populations in an Urbanization Gradient. Acta Theriologica, 23, 341-358. https://doi.org/10.4098/AT.arch.78-24

[22] Petrusewicz, K. and Macfadyen, A. (1970) Productivity of Terrestrial Animals: Principles and Methods. IBP Handbook No. 13, Blackwell Science Publ., Oxford, 1-190.

[23] Gliwicz, J. (1981) Competitive Interactions within a Forest Rodent Community in Central Poland. Oikos, 37, 353-362. https://doi.org/10.2307/3544128

[24] Kozakiewicz, A. (1987) Spatial Distribution and Interspecific Interactions in Small Rodent Community of a Lake Coastal Zone. Acta Theriologica, 32, 433-447. https://doi.org/10.4098/AT.arch.87-30

[25] Pieniążek, A.O. (2014) The Role of the Vistula River in Shaping the Genetic Structure of Small Mammal Populations in Warsaw. In: Indykiewicz, P., Jerzak, L. and Barczak, T., Eds., Fauna of Cities. Preservation of Biodiversity in Cities, ATR, Bydgoszcz, 337-345.

[26] Young, T.P., Chase, J. and Huddleston, R. (2001) Community Succession and Assembly: Comparing, Contrasting and Combining Paradigms in the Context of Ecological Restoration. Ecological Restoration, 19, 5-18. https://doi.org/10.3368/er.19.1.5

[27] Fukami, T., Bezemer, T.M., Mortimer, S.R. and van der Putten, W.H. (2005) Species Divergence and Trait Convergence in Experimental Plant Community Assembly. Ecology Letters, 8, 1283-1290. https://doi.org/10.1111/j.1461-0248.2005.00829.x

[28] Fukami, T. (2004) Assembly History Interacts with Ecosystem Size to Influence Species Diversity. Ecology, 85, 3234-3242. https://doi.org/10.1890/04-0340

[29] Morin, P.J. (1987) Predation, Breeding Asynchrony, and the Outcome of Competition among Treefrog Tadpoles. Ecology, 68, 675-683.

https://doi.org/10.2307/1938473 
Submit or recommend next manuscript to SCIRP and we will provide best service for you:

Accepting pre-submission inquiries through Email, Facebook, LinkedIn, Twitter, etc. A wide selection of journals (inclusive of 9 subjects, more than 200 journals)

Providing 24-hour high-quality service

User-friendly online submission system

Fair and swift peer-review system

Efficient typesetting and proofreading procedure

Display of the result of downloads and visits, as well as the number of cited articles Maximum dissemination of your research work

Submit your manuscript at: http://papersubmission.scirp.org/

Or contact nr@scirp.org 